\title{
Isolation \& Characterisation of Beta-sitosterol from the rhizomes of Arisaema utile and its Evaluation for Antioxidant Activity
}

\author{
Arif Hussain Bhat ${ }^{1 *}$, Aparna Alia ${ }^{2}$, Ghulam Mustafa Rather $^{1}$ \& Bharty Kumar ${ }^{1}$ \\ ${ }^{1}$ Department of Botany, Government M.V.M. Bhopal, Madhya Pradesh, India \\ ${ }^{2}$ Department of Botany, Rajeev Gandhi College, Shahpura, Bhopal, Madhya Pradesh, India \\ *Corresponding Author: arifbhat96@gmail.com
}

Available online at: www.isroset.org

Received: 06/Apr/2019, Accepted: 18/Apr/2019, Online: 30/Apr/2019

\begin{abstract}
The aim of this study is isolation, identification and characterized the bioactive compounds from the rhizomes of arisaema utile. Preliminary Phytochemical screening of the rhizome extract of arisaema utile revealed the presence of Steroids, terpenoids, Flavonoids, Alkaloids, Saponins \& Carbohydrates. The air dried rhizomes were pulverized to powder, subjected to Soxhlet extraction and compound Isolation. The isolated compound was colorless crystalline, which was further subjected to IR, ${ }^{13} \mathrm{CNMR}$ and ${ }^{1} \mathrm{HNMR}$ for proper characterization and elucidation of the structure. The compound was concluded as $\beta$ Sitosterol. Antioxidant activity of the isolated compound was measured by DPPH assay under in-vitro condition. The isolated compound showed most promising radical scavenging activity at concentration of $10 \mu \mathrm{g} / \mathrm{ml}$.
\end{abstract}

Keywords: $\beta$-Sitosterol, Antioxidant activity, DPPH, arisaema utile, and Chromatography.

\section{INTRODUCTION}

A substantial part of all drugs are still based on compounds originally isolated from nature. The plant kingdom is a treasure house of potential drugs and in the recent years there has been an increasing awareness about the importance of medicinal plants. Drugs from the plants are easily available, less expensive, safe, and efficient and rarely have side effects. Arisaema is a genus of about 150 species in the flowering plant family Araceae, native to eastern Africa, central Africa, Asia and eastern North America. Asiatic species are often called cobra lilies, while western species are often called jack-in-the-pulpit. It can be found growing on rocky slopes at an altitude of 2,400-4,600 meters. It grows in shady, moist, well-drained and fertile soil. Arisaemas are tuberous perennials that die back to the ground in winter. Arisaema utile emerges in spring. Most of the species from genus Araceae have a history of use in folk medicine for the treatment of various infectious diseases. Rhizomes of few species of Arisaema have long history of use in Traditional Medicine, especially in Asian countries like Arisaema jacquemontiana for Muscular strength and Skin infections, Arisaema propinquum for Skin eruption or rashes etc [1]. Many medicinal plants have been screened extensively for their antimicrobial potential worldwide $[\mathbf{2}, \mathbf{3}$, 4]. Further, plant phenolic compounds have been found to possess potent antioxidant [4-9], antimicrobial and anticancer activities [10, 11]. As an individual plant, Arisaema utile is used for treating various infections in the blood, liver and bile which correlates to the signs and symptoms of parasitic and microbial infections, cancer and inflammatory conditions. A lectin was also purified from tubers of Himalayan cobra lily Arisaema utile [12]. One of the most exiting properties resulting out of the interaction of lectins with lymphocytes is mitogenicity, i.e. the triggering of quiescent, non-dividing lymphocytes into a state of growth and proliferation. The discovery of first mitogenic lectin Nowell [13] led to the detection of many other such lectins, most notably concanavalin A [14], Wheat germ agglutinin [15] and Pokeweed mitogen [16]. The crude extracts of this plant as mentioned above showed significant antimicrobial, antioxidant and prominent cytotoxic activities against few cancer cell lines. The plant has reports of being used in traditional medicines by the tribal people of Jammu and Kashmir for curing various diseases. Keeping in view global and national scenario of medicinal plants, Encouraged by these finding, we carried out in-depth phytochemical isolation and further investigate the antifungal and antioxidant activities of the isolated compound from arisaema utile especially existing at high altitudes of Jammu and Kashmir with proven folklore medicinal claim.

\section{MATERIALS AND METHODS}

Collection of Plant material and processing:

The Arisaema utile plant material was collected in the month of July from Gulmarg area of district Budgam of Jammu \& Kashmir state, India. Voucher specimen of Arisaema utile bearing specimen no 27911, was Identified and deposited at KASH herbarium in 
centre of biodiversity and plant taxonomy, University of Kashmir, Srinagar, J\&K, India.. The rhizomes of the plant were shade dried, then pulverized into powder with the aid of grinder. The powder obtained from the plant was then used for the isolation of constituents using Soxhlet extraction and Column Chromatography.

\section{Extraction and purification:}

Eight hundred grams $(800 \mathrm{~g})$ of powdered rhizome of arisaema utile was subjected to sequential extraction using soxhlet apparatus from non polar to polar solvents such as $n$-hexane < ethyl acetate < methanol. The solvent was recovered under reduced pressure using rotary evaporator under vacuum condition and the residue was stored in the refrigerator. Hexane extract was chromatographed on a silica gel column and eluted with solvent mixtures of increasing polarity, composed of hexane, ethyl acetate and methanol. All the fractions were monitored on TLC. Fractions collected with 20:80 ethyl acetate/Hexane were pulled together as these fractions showed a single spot on TLC. Further these combined fractions were kept in refrigerator overnight for crystallization which resulted in the formation of crystalline needle shaped compound 1. The structure of the isolated compound was established on the basis of elemental analysis and spectroscopic evidences (IR, ${ }^{1} \mathrm{HNMR}$, $\left.{ }^{13} \mathrm{CNMR}\right)$. The structure was simulated using ACD/NMR program to obtain the chemical shifts of both proton and carbon.

\section{Spectroscopic characterization of Compound 1}

The various spectroscopic methods like FT-IR, DEPT, ${ }^{1} \mathrm{H}-\mathrm{NMR}$, and ${ }^{13} \mathrm{C}-\mathrm{NMR}$ were used to elucidate the structure of isolated compounds. The Fourier Transform-Infrared (FTIR) spectroscopy was carried out on a Perkin Elmer FTIR fitted with Spectrum software version 10.3.2 using a liquid sampler. ${ }^{1} \mathrm{H}-\mathrm{NMR}$ (400MHz) and ${ }^{13} \mathrm{C}-\mathrm{NMR}$ (400MHz) were recorded using $\mathrm{CDCl}_{3}$ as solvent in $\mathbf{M e O D}$ on Bruker, Avance (400MHz) NMR spectrometer.

\section{Determination of antioxidant activity}

The in-vitro antioxidant potential of the isolated compounds was measured in terms of hydrogen donating or free radical scavenging ability using the stable radical DPPH according to the standard procedure [17]. $0.1 \mathrm{mM}$ solution of DPPH in Methanol was prepared and $1.0 \mathrm{ml}$ of this solution was added to $1.0 \mathrm{ml}$ of the test solution in methanol at different concentrations of Isolated Compounds (2, 4, 8, 10 \& $12 \mu \mathrm{g} / \mathrm{mL})$. The reaction mixture was incubated at $37^{\circ} \mathrm{C}$ for $30 \mathrm{~min}$ in darkness. The absorbance of the sample at $517 \mathrm{~nm}$ was measured and then compared with that of a control solution containing the reaction mixture amended methanol instead of Isolated Compounds. Ascorbic acid (2, 4, 8, 10 \& $12 \mu \mathrm{g} / \mathrm{mL}$ ) was used as the standard reference compound, and the percentage of DPPH free radical scavenging activity was calculated using the following equation:

$\%$ scavenging activity $=\left(\left(\mathrm{A}_{0}-\mathrm{A}\right) / \mathrm{A}_{0} \times 100\right)$.

Where $\mathrm{A}_{0}$ was the absorbance of the control (blank, without compound) and $\mathrm{A}$ was the absorbance of the reaction mixture. All the tests were performed in triplicate and the graph was plotted with the mean values.

\section{RESULTS AND DISCUSSION}

\section{A. Fourier Transform-Infrared (FT-IR) spectroscopy}

The IR absorption spectrum of Compound 1 showed absorption peaks at $3332.2 \mathrm{~cm}^{-1}$ (O-H stretching.); 2937.1 $\mathrm{cm}^{-1}$ and $2870.1 \mathrm{~cm}^{-1}$ (aliphatic C-H stretching); $1632.6 \mathrm{~cm}^{-1}$ $(\mathrm{C}=\mathrm{C}$ absorption peak); other absorption peaks includes $1461.1 \mathrm{~cm}^{-1}$ (CH2); $1379.1 \mathrm{~cm}^{-1}$ (OH def), $1043.7 \mathrm{~cm}^{-1}$ (cycloalkane) and $797.7 \mathrm{~cm}^{-1}$. (Phg. 1). The compound is a colourless crystalline compound, $\lambda_{\max }$ in $\mathrm{CHCl}_{3}: 220 \mathrm{~nm}$. On subjection to IR spectroscopic analysis, absorptions bands appeared between $3570.36-3186.51 \mathrm{~cm}^{-1}$ that is characteristic of $\mathrm{O}-\mathrm{H}$ stretching , $2870.1 \mathrm{~cm}-1$ is due aliphatics or $\mathrm{C}-\mathrm{H}$ stretching or $\left(\mathrm{CH}_{3}\right), 1632.6 \mathrm{~cm}^{-1}$ due to double $(\mathrm{C}=\mathrm{C})$ stretching, $1043.7 \mathrm{bcm}^{-1}$ due to $(\mathrm{C}-\mathrm{O})$. Other absorption frequencies include $1379.1 \mathrm{~cm}^{-1}$ is a bending frequency for cyclic $\left(\mathrm{CH}_{2}\right)_{n}$. The absorption frequency at $797.7 \mathrm{~cm}^{-1}$ signifies cycloalkane. These absorption frequencies resemble the absorption frequencies observed for $\beta$-sitosterol as resembled data published by Arjun patra and his co-workers. [18].

\section{B. Nuclear magnetic resonance (NMR) sepectroscopy}

$\mathrm{H}-\mathrm{NMR}\left(\mathrm{CDCl}_{3}, 400 \mathrm{MHz}\right)$ of compound $\mathbf{1}$ has given signals at $\delta 3.56(1 \mathrm{H}, \mathrm{m}, \mathrm{H}-3), 5.38(1 \mathrm{H}, \mathrm{m}, \mathrm{H}-6), 0.72(3 \mathrm{H}$, $\mathrm{m}, \mathrm{H}-18), 1.05(3 \mathrm{H}, \mathrm{m}, \mathrm{H}-19), 0.80(3 \mathrm{H}, \mathrm{m}, \mathrm{H}-26), 0.90(1 \mathrm{H}$, d, $\mathrm{H}-21), 0.84(3 \mathrm{H}, \mathrm{m}, \mathrm{H}-27), 5.08(1 \mathrm{H}, \mathrm{m}, \mathrm{H}-22), 5.18$ (1H,m, H-23), 2.03 (m, H-10), 1.87 (2H, m, H-11), 1.90 (1H, m, H-14), 1.92 (2H, m, H-15), 2.27 (1H, m, H-17), 0.94 (1H, br., H-24) and 0.83 (3H, m, H-29), ppm. (Phg. 2). The H-NMR spectrum $\left(400 \mathrm{MHz}, \mathrm{CDCl}_{3}\right)$ of compound 1 has revealed a one proton multiplet at $\delta 2.41$, the position and multiplicity of which was indicative of $3 \mathrm{H}$ of the steroid nucleus. The typical $6 \mathrm{H}$ of the steroidal skeleton was evident as a multiplet at $\delta 5.38$ that integrated for one proton. The spectrum further revealed signals at $\delta 1.47$ and $\delta 1.19(3 \mathrm{H}$ each) assignable to two tertiary methyl group at C- 18 and C-19 respectively. The HNMR spectrum showed two doublets centered at $\delta 0.90(\mathrm{~J}=6.7 \mathrm{~Hz})$ and $\delta 0.89(\mathrm{~J}=$ $6.7 \mathrm{~Hz}$ ) which could be attributed to two methyl groups at C26 and $\mathrm{C}-27$ respectively. The doublet at $\delta 1.62(\mathrm{~J}=6.5 \mathrm{~Hz})$ was demonstrative of a methyl group at C-21. On the other hand, the triplet of three proton intensity at $\delta 0.88$ could be assigned to the primary methyl group at C- 29. This compound is having six methyl, eleven methylene and three quaternary carbons with a hydroxyl group. The above spectral features are in closed agreement to those observed for $\beta$ - Sitosterol according to Manoharan et al., 2005 and 
Escudero et al., 1985 [19, 20]. (Table 1) shows the ${ }^{1} \mathrm{H}-\mathrm{NMR}$ and ${ }^{13} \mathrm{C}-\mathrm{NMR}$ values in comparison with the previous data available.

13

C-NMR and DEPT (Phg. 3 \& Phg. 4) $\left(\mathrm{CDCl}_{3}, 100 \mathrm{MHz}\right)$ of compound 1 has given signal at 140.8(C-5), 121.7(C-6), 71.8(C-3), 56.8(C-14), 56.09(C-17), 50.17(C-9), 45.87(C24), 42.35(C-13), 42.34(C-4), 40.8(C-20), 39.8(C-12), $37.28(\mathrm{C}-1), \quad 36.5(\mathrm{C}-10), \quad 36.1(\mathrm{C}-20), \quad 33.97(\mathrm{C}-22)$, 31.9(C-7), 31.7(C-8), 29.2(C-25), 28.26(C-16), 29.19(C-2), 24.32(C-15), 23.10(C-28), 26.12(C-23), 21.11(C-11), 19.83(C-26), 19.4(C-27), 19.06(C-19), 18.80(C-21), $11.89(\mathrm{C}-18), 12.00(\mathrm{C}-29)$
The ${ }^{13} \mathrm{C}$-NMR of compound $\mathbf{1}$ has shown recognizable signals at 140.8 and $121.7 \mathrm{ppm}$, which are assigned C5 and C6 double bonds respectively. The value at $24.32 \mathrm{ppm}$ corresponds to angular carbon atom (C-15). Spectra show twenty nine carbon signal including six methyls, nine methylenes, eleven methane and three quaternary carbons. The alkene carbons appeared at 140.8 and $121.7 \mathrm{ppm}$. The structure was simulated using $\mathrm{ACD} / \mathrm{NMR}$ program to obtain the chemical shifts of both proton and carbon. The above spectral features are in closed agreement to those observed for $\beta$ - Sitosterol according to Manoharan et al., 2005 and Escudero et al., 1985 [19, 20]. On comparison the standard data matched with the simulated data which supports the proposed structure of this compound as $\beta$-Sitosterol.

Table 1. ${ }^{1} \mathrm{H},{ }^{13} \mathrm{C}$-NMR chemical shift values for compound-1 in comparison with those reported in literature

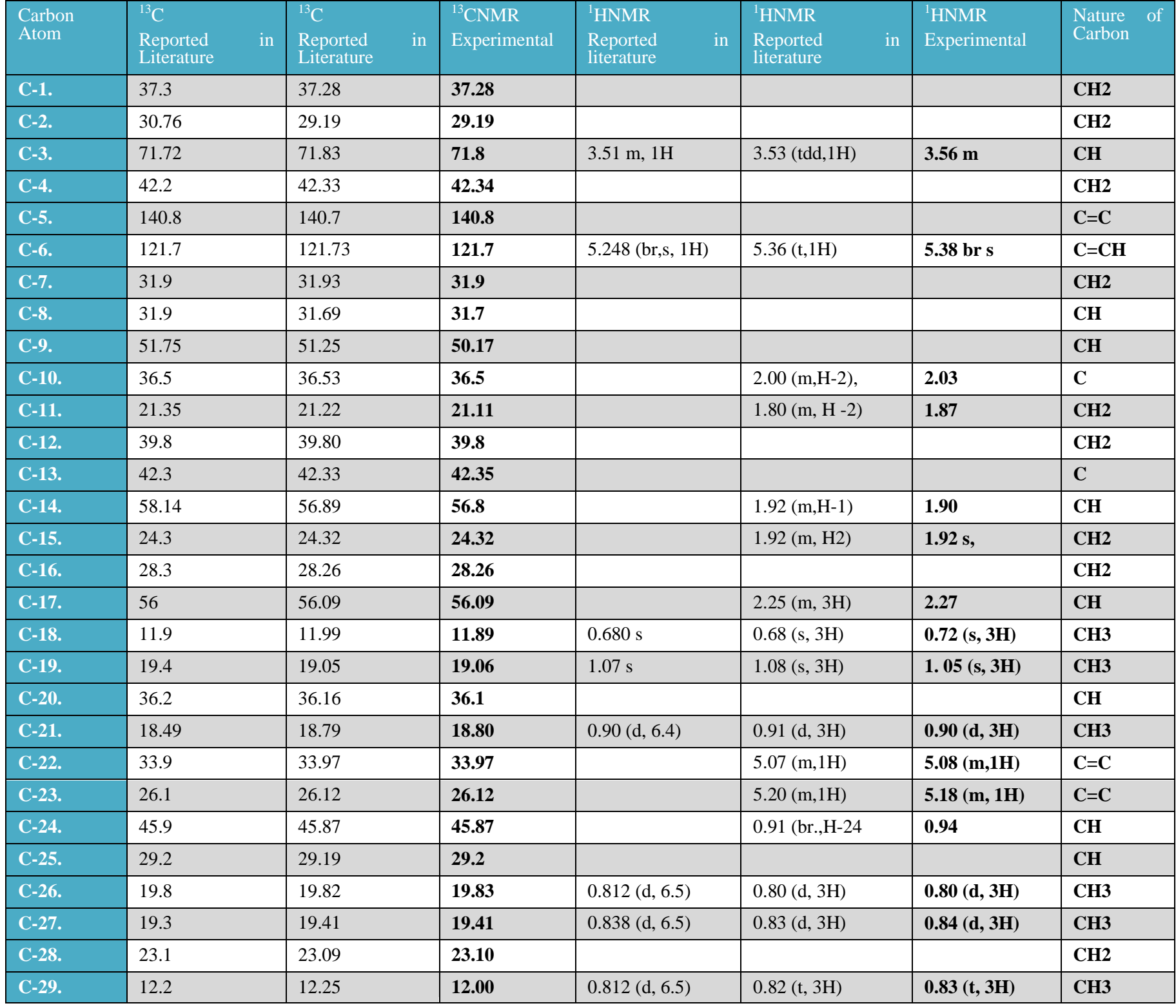




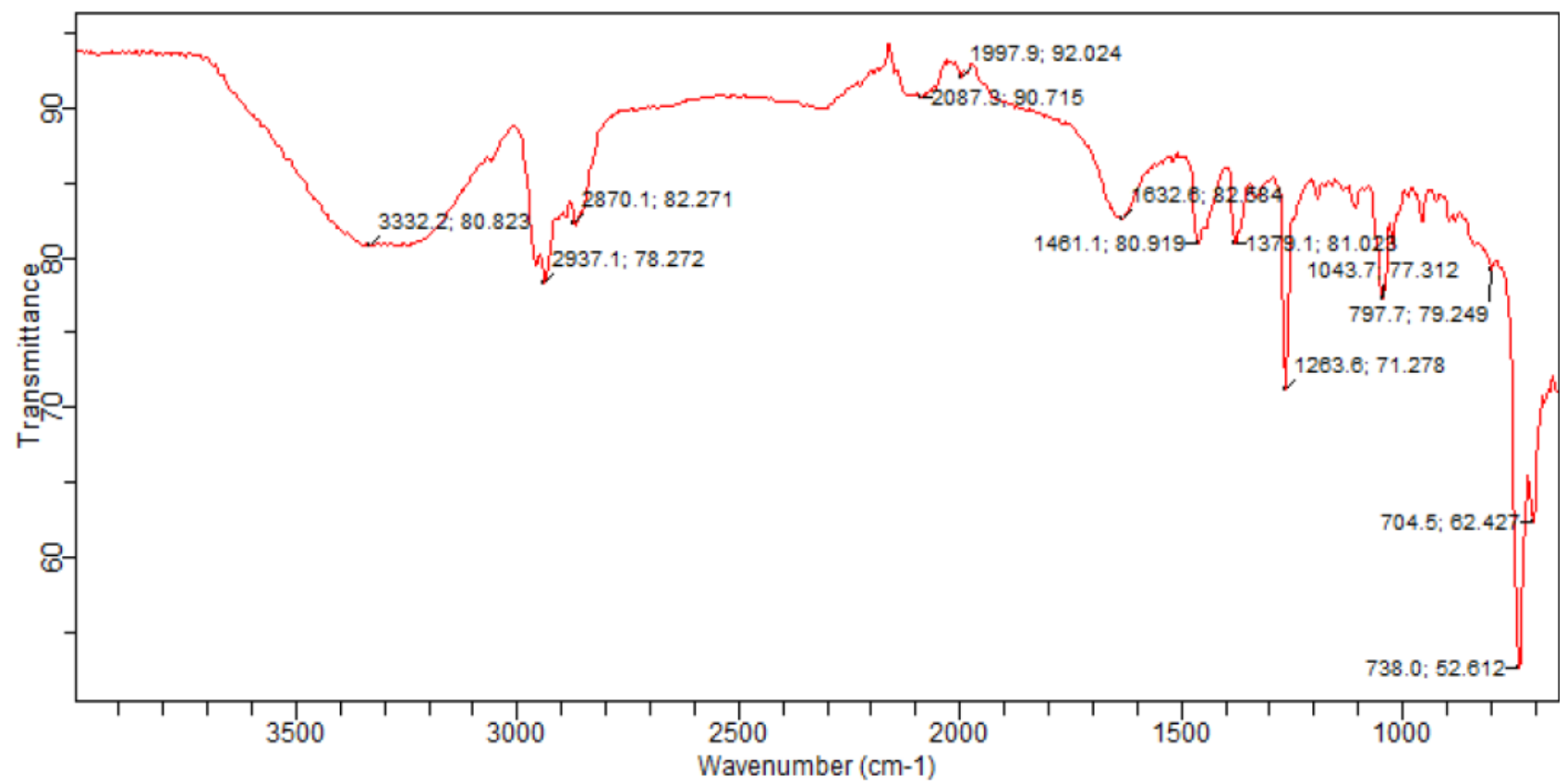

Phg. 1. IR absorption spectra of Compound-1

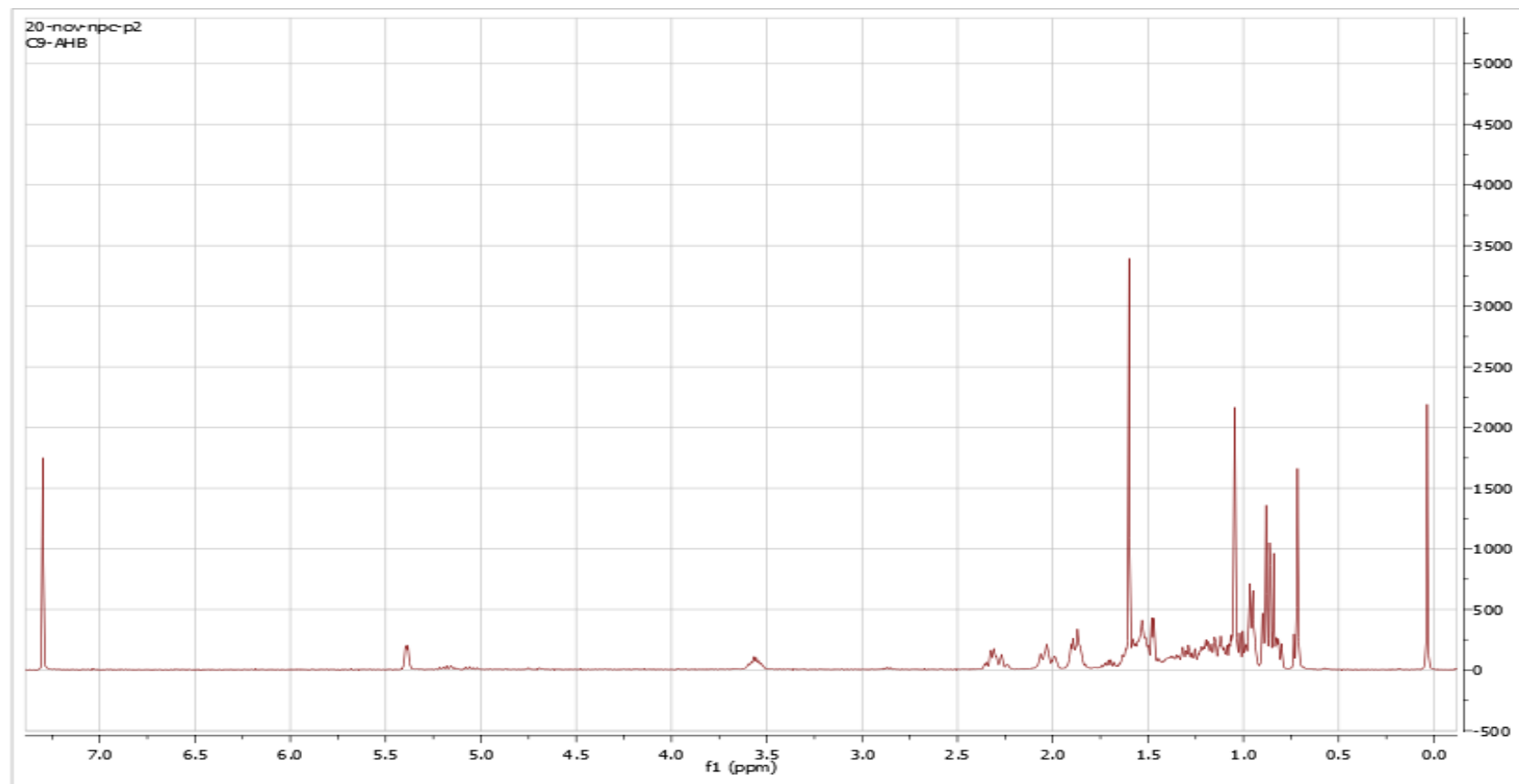

Phg. 2. ${ }^{1} \mathrm{H}-\mathrm{NMR}$ absorption spectra of Compound-1 


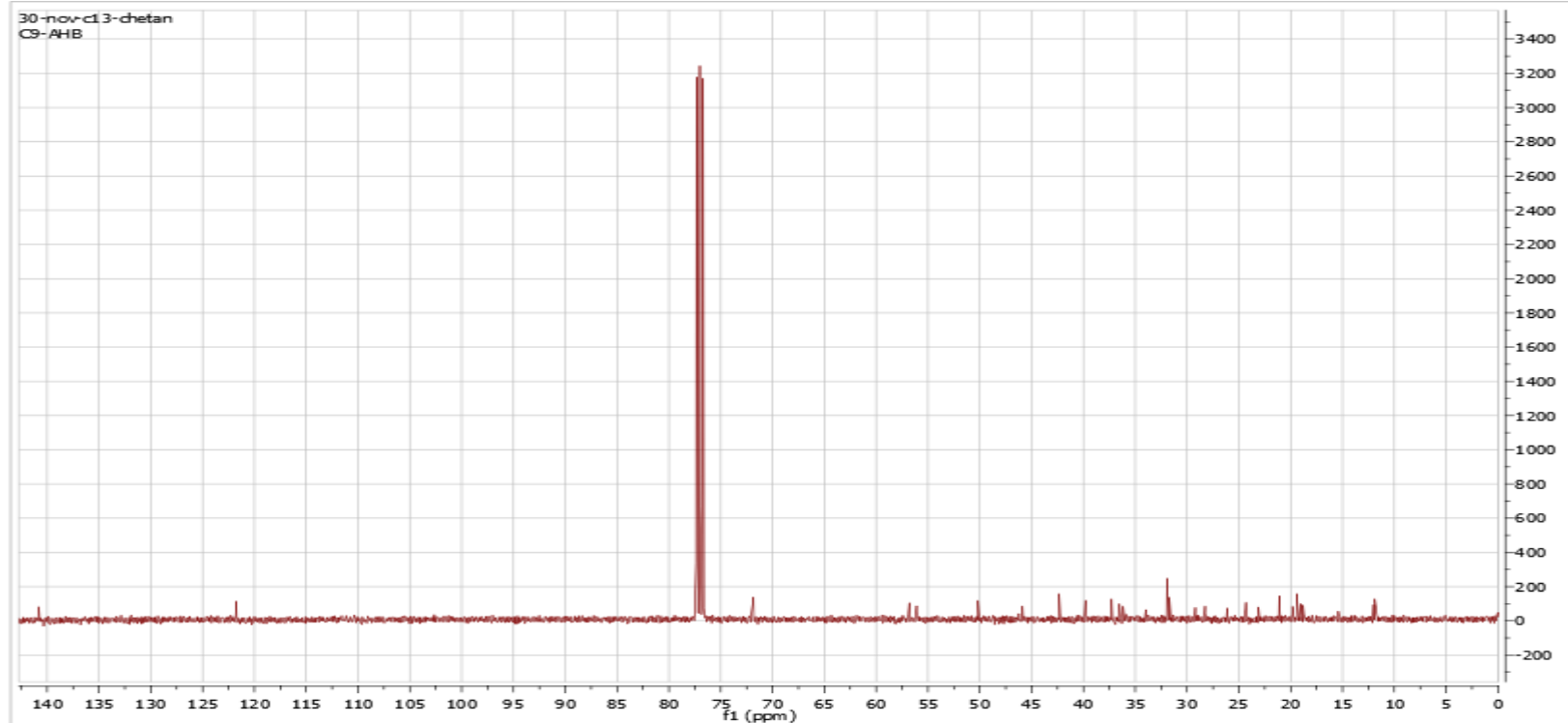

Phg. $3 .{ }^{13} \mathrm{C}$-NMR absorption spectra of Compound-1

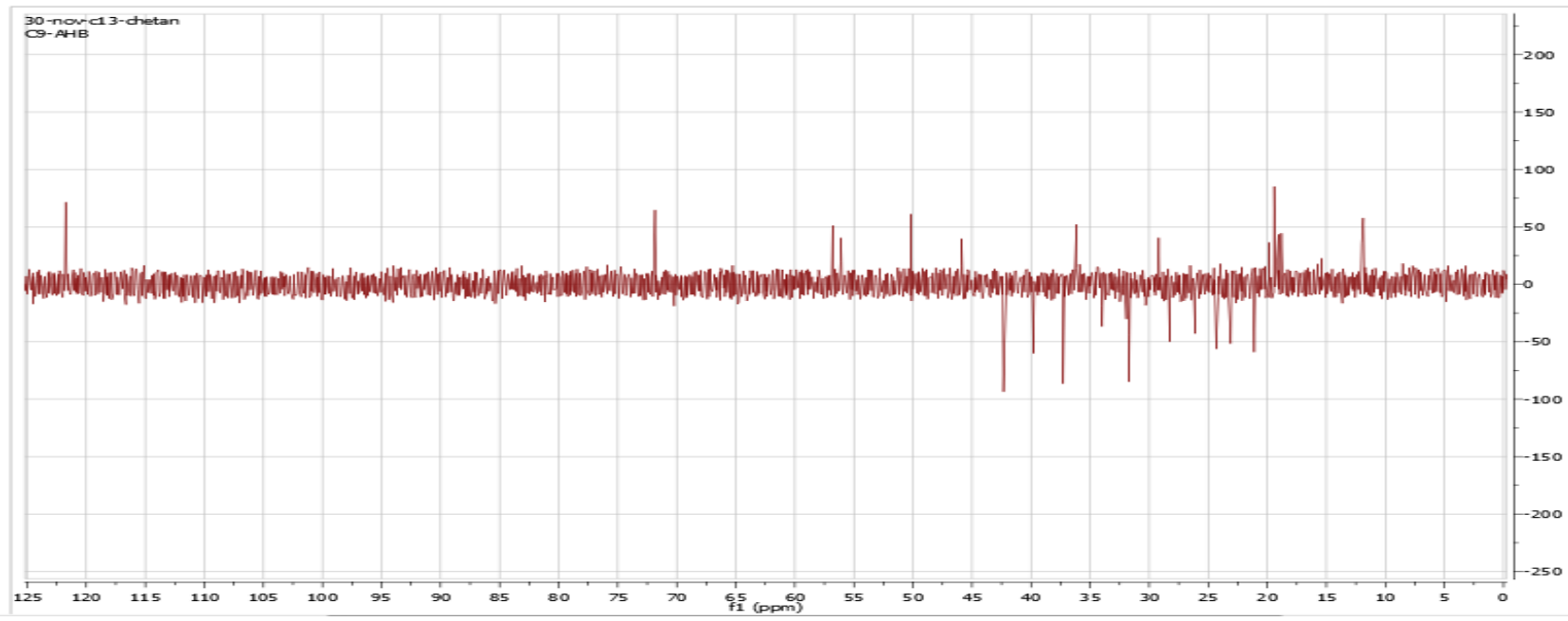

Phg. 4. DEPT absorption spectra of Compound-1

\section{Tests for steroid}

i). Salkowski reaction: A few crystals of compound 1 were dissolved in $2 \mathrm{ml}$ of chloroform followed by the careful addition of $3 \mathrm{ml}$ concentrated $\left(\mathrm{H}_{2} \mathrm{SO}_{4}\right)$. A reddish color was seen in the upper chloroform layer, indicative of steroid ring [21].

ii). Liebermann burchard reaction: A few crystals of compound 1 were dissolved in chloroform and a few drops of concentrated sulfuric acid were added to it followed by addition of 2-3 drops of acetic anhydride. Solution turned violet blue and finally green or green-blue coloured after a few minutes thus positive indication of steroid ring [21].

Phytochemical tests (Salkowski's test and LiebermanBurchard test) of the compound $\mathbf{1}$ confirm its steroidal nature. Since, the NMR machine indicated steroidal nucleus and the compound gives positive test for steroids so all of the other structures other than steroids were rejected. Based upon the functional group analysis it was found that the nature of oxygen was hydroxyl, also supported by IR spectroscopy (Perkin Elmer FT-IR). This implies presence of one double bond in the structure. So, the steroids with other functional groups were rejected. Also on considering the nature of oxygen as hydroxyl and presence of one double bond, the general formula for the compound is $\mathrm{C}_{\mathrm{n}} \mathrm{O}$. The exact molecular mass for the formula is found to be 414.37 and the chemical formula could be tentatively $\mathrm{C}_{29} \mathrm{H}_{50} \mathrm{O}$. Therefore it must be a tetra cyclic compound. Based on the analysis of spectral data (IR, ${ }^{13} \mathrm{C}-\mathrm{NMR}$, HNMR and DEPT) the structure of the isolated compound $\mathbf{1}$ is proposed as (Fig. 1); 


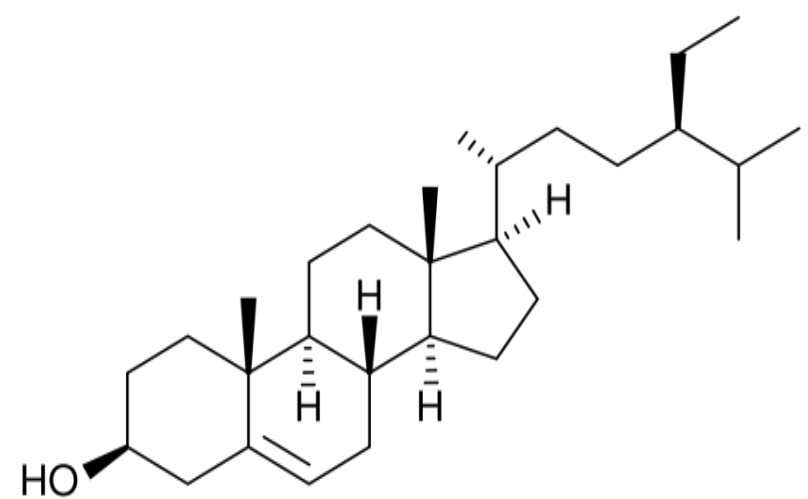

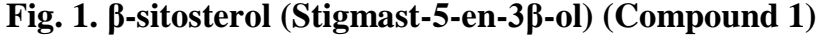

$\boldsymbol{\beta}$-sitosterol is a natural micro-nutrient which is found in the cells and membranes of all oil producing plants, fruit, vegetables, grains, seeds and trees. It has been proven to be a safe, natural and effective nutritional supplement and has shown amazing potential benefits in many diverse applications. Presence of $\beta$-sitosterol has been reported in various plants, such as leaves of Ocimum sanctum [22], rhizomes of the Stylochiton lancifolius [23], fruits of Corylus colurna Linn [24] and Solanum xanthocarpum [25] as well as in the tissue cultures of Adhatoda vasica \& Ageratum conyzoides [26] and cell suspension culture of Chrysanthemum coronarium L. [27].

\subsection{1c. Antioxidant activity}

DPPH free radical scavenging capacity of the compound 1 was measured by DPPH assay under in-vitro conditions. The ability of the examined Compound-1 and its derivatives to act as donor for hydrogen atoms in the transformation of DPPH radical into its reduced form $\mathrm{DPPH}_{2}$ was investigated. The examined samples were able to reduce the stable purple coloured DPPH radical into yellow coloured $\mathrm{DPPH}_{2}$ (Table 2). Compound 1 showed most promising radical scavenging activity at concentration of $8 \mu \mathbf{g} / \mathbf{m l}$. These results are plotted in the form of graph (Fig. 2). Similar type of results for antioxidant activity of Beta-sitosterol has been previously reported by variours researchers. Several findings suggest that beta-sitosterol has antioxidant property [28, 29]. It has also been shown to modulate antioxidant enzymes and human estrogen receptor [30]. It has been reported from a study that beta-sitosterol reduced Oxygen free radical and Hydrogen Peroxide levels in Phorbol myristate acetate (PMA) stimulated RAW 264.7 cells but does not function as a radical scavenger [31]. Glutathione peroxidase (GSH) and Mn superoxide dismutase (SOD) activities are decreased significantly by beta-sitosterol treatment [32]. The efficacy of phytosterols especially Beta-sitosterol extracted from Diascorea alata on antioxidant activities, plasma lipids and hematological profiles was assessed in postmenopausal women by Hsu et al., 2017 [33]. Several other species are reported to possess Beta-sitosterol as an active antioxidant compound (Suhaj, 2006) [34]. These reports from previous literature further strengthen results of our experimental findings.

Table 2. Antioxidant activity of Compound-1

\begin{tabular}{|c|c|c|c|c|c|}
\hline Concentrations & $2 \mu \mathrm{g} / \mathrm{ml}$ & $4 \mu \mathrm{g} / \mathrm{ml}$ & $8 \mu \mathrm{g} / \mathrm{ml}$ & $10 \mu \mathrm{g} / \mathrm{ml}$ & $12 \mu \mathrm{g} / \mathrm{ml}$ \\
\hline \%age inhibition of Comp. 1 & $30 \%$ & $25 \%$ & $41.66 \%$ & $20.83 \%$ & $28.33 \%$ \\
\hline \%age inhibition Asc. Acid & $53.3 \%$ & $58.3 \%$ & $64.16 \%$ & $68.33 \%$ & $62.5 \%$ \\
\hline
\end{tabular}

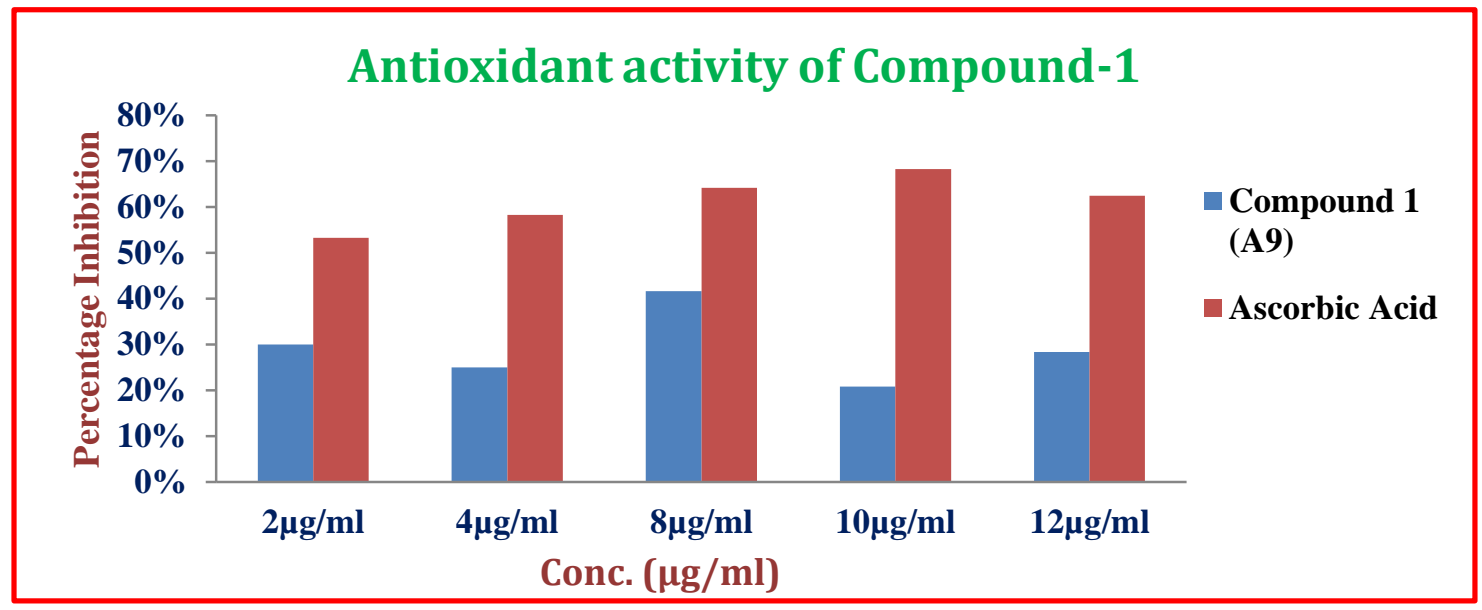

Fig. 2. DPPH radical scavenging activity of Compound-1 


\section{CONCLUSION}

In our study an attempt was made to isolate the compounds for the first time from rhizomes of Arisaema utile and highlight antioxidant potential of the isolated compounds. In our study a steroid was isolated and reported for the first time from rhizomes of Arisaema utile and its antioxidant potential was evaluated. The structure of the isolated compound was identified beta-sitosteroid on the basis of spectroscopic methods and by comparing their physical properties reported in the literature. Beta-sitosterol is mainly known and used for its cholesterol lowering property. But studies have shown that the phytochemical may have other health benefits: reducing risk of cancer, prevention of fungal infections and prevention of oxidative damage through its antioxidant activity. The results of the present study suggest that the isolated compound (Beta-sitosterol) from Arisaema utile shows promising antioxidant activity. Therefore this plant can hopefully be considered in future for more clinical evaluations and possible applications. We should maintain our efforts in considering and valorizing our natural patrimony as well as conducting more research on Arisaema utile with an aim to isolate some Novel compounds with promising pharmacological aspects.

\section{ACKNOWLEDGMENT}

We would like to Thank Azra N. Kamili Director, Centre of Research for Development (CORD), and Professor (Dr.) Bashir Ahmad Ganai Head, Department of Environmental Science, University of Kashmir, Srinagar for proving Lab facilities and necessary support.

\section{REFERENCES}

[1]. Ahmed S, \& Ajaz T (2017). An Ethnobotanical Survey of Medicinal Plants used by Gujjar and Bakerwal Community of Tehsil Manjakote of District Rajouri J\&K State (India). International Journal of Engineering Science, 4142.

[2]. Kaur, G. J., \& Arora, D. S. (2009). Antibacterial and phytochemical screening of Anethum graveolens, Foeniculum vulgare and Trachyspermum ammi. BMC complementary and alternative medicine, $9(1), 30$.

[3]. Mothana, R. A., Lindequist, U., Gruenert, R., \& Bednarski, P. J. (2009). Studies of the in vitro anticancer, antimicrobial and antioxidant potentials of selected Yemeni medicinal plants from the island Soqotra. BMC Complementary and Alternative Medicine, 9(1), 7 .

[4]. Adedapo, A. A., Jimoh, F. O., Koduru, S., Masika, P. J., \& Afolayan, A. J. (2009). Assessment of the medicinal potentials of the methanol extracts of the leaves and stems of Buddleja saligna. BMC Complementary and Alternative Medicine, 9(1), 21.

[5]. Adesegun, S. A., Fajana, A., Orabueze, C. I., \& Coker, H. A. B. (2009). Evaluation of antioxidant properties of Phaulopsis fascisepala $\quad \mathrm{CB} \quad \mathrm{Cl}$.(Acanthaceae). Evidence-Based Complementary and Alternative Medicine, 6(2), 227-231.

[6]. Hutadilok-Towatana, N., Chaiyamutti, P., Panthong, K., Mahabusarakam, W., \& Rukachaisirikul, V. (2006). Antioxidative and free radical scavenging activities of some plants used in Thai folk medicine. Pharmaceutical biology, 44(3), 221-228.

[7]. Wang, K. J., Yang, C. R., \& Zhang, Y. J. (2007). Phenolic antioxidants from Chinese toon (fresh young leaves and shoots of Toona sinensis). Food chemistry, 101(1), 365-371.

[8]. Gacche, R. N., \& Dhole, N. A. (2006). Antioxidant and possible anti-inflammatory potential of selected medicinal plants prescribed in the Indian traditional system of medicine. Pharmaceutical biology, 44(5), 389-395.

[9]. Chang, H. C., Huang, G. J., Agrawal, D. C., Kuo, C. L., Wu, C. R., \& Tsay, H. S. (2007). Antioxidant activities and polyphenol contents of six folk medicinal ferns used as "Gusuibu". Botanical Studies, 48(4), 397-406.

[10]. Alcaraz, L. E., Blanco, S. E., Puig, O. N., Tomas, F., \& Ferretti, F. H. (2000). Antibacterial activity of flavonoids against methicillinresistant Staphylococcus aureus strains. Journal of Theoretical Biology, 205(2), 231-240.

[11]. Cushnie, T. T., \& Lamb, A. J. (2005). Antimicrobial activity of flavonoids. International journal of antimicrobial agents, 26(5), 343-356.

[12]. Goldstein, I. J. (1980). What should be called a lectin?. Nature, $285,66$.

[13]. Nowell, P. C. (1960). Phytohemagglutinin: an initiator of mitosis in cultures of normal human leukocytes. Cancer research, 20(4), 462-466.

[14]. Harris, H., \& Robson, E. B. (1963). Precipitin reactions between extracts of seeds of Canavalia ensiformis (Jack Bean) and normal and pathological serum proteins. Vox sanguinis, 8(3), 348-355.

[15]. Aub, J. C., Sanford, B. H., \& Wang, L. H. (1965). Reactions of normal and leukemic cell surfaces to a wheat germ agglutinin. Proceedings of the National Academy of Sciences, 54(2), 400-402.

[16]. Brittinger, G., \& König, E. (1969). Lymphocytenstimulierung durch Pokeweed-Mitogen (PWM). Klinische Wochenschrift, 47(24), 1307-1313.

[17]. Braca, A., De Tommasi, N., Di Bari, L., Pizza, C., Politi, M., \& Morelli, I. (2001). Antioxidant principles from bauhinia $t$ arapotensis. Journal of natural products, 64(7), 892-895.

[18]. Patra, A., Jha, S., Murthy, P. N., \& Manik, S. A. (2010). Isolation and characterization of stigmast-5-en-3 $\beta$-ol ( $\beta$-sitosterol) from the leaves of Hygrophila spinosa T. Anders. Int $J$ Pharma Sci Res, 1(2), 95-100.

[19]. Manoharan, K. P., Benny, T. K. H., \& Yang, D. (2005). Cycloartane type triterpenoids from the rhizomes of Polygonum bistorta. Phytochemistry, 66(19), 2304-2308.

[20]. Escudero, J., López, J. C., Rabanal, R. M., \& Valverde, S. (1985) Secondary metabolites from Satureja species. New triterpenoid from Satureja acinos. Journal of Natural Products, 48(1), 128131.

[21]. Harbone, B. (1984). Phytochemical methods. 2nd. New York, Champan Hall, 4, 4-7.

[22]. Rahman SMM, Mukta ZA, Hossain MA (2009) Isolation and characterization of $\beta$-sitoterol-D-glycoside from petroleum extract of the leaves of Ocimum sanctamum L. As J Food Ag-Ind 2(1): 39-43.

[23]. Pateh U, Haruna AK, Garba M, Iliya I, Sule IM, Abubakar MS, Ambi AA (2009) Isolation of stigmasterol, $\beta$-sitoterol and 2hydroxyhexadecanoic acid methyl ester from the rhizomes of the Stylochiton lancifolius Pyer and Kotchy (Araceae). Nig J Pharm Sci 8(1): 19-25

[24]. Akhtar, P., Ali, M., Sharma, M. P., Farooqi, H., \& Khan, H. N. (2010). Phytochemical investigation of fruits of Corylus colurna Linn. Journal of phytology.

[25]. Khanam S and R Sultana (2012) Isolation of $\beta$-sitoterol and stigmasterol as active immunomodulatory constituent from the 
fruits of Solanum xanthocarpum (Solanaceae). IJPSR 3(4): 10571060

[26]. Sarin R, Bansal N (2011) Phytosterol from invivo and invitro cultures of two medicinal plants viz. Adhatoda vasica and Ageratum conizoidus. IJRAP 2(3): 927-930

[27]. Kim HC, Chung HY, Lee SY, Kim YJ, Baek NI, Kim SH, Choi GW, Kim DK, Kwon BM, Park MH, Chung IS (2005) Production of $\beta$-sitoterol by cell suspension culture of Chrysanthemum coronarium L. J Korian Soc Appl Bio Chem 48 (4): 425-430

[28]. Paniagua-Pérez, R., Madrigal-Bujaidar, E., Reyes-Cadena, S., Molina-Jasso, D., Gallaga, J. P., Silva-Miranda, A., ... \& Chamorro, G. (2005). Genotoxic and cytotoxic studies of betasitosterol and pteropodine in mouse. BioMed Research International, 2005(3), 242-247.

[29]. Gupta, R., Sharma, A. K., Dobhal, M. P., Sharma, M. C., \& Gupta, R. S. (2011). Antidiabetic and antioxidant potential of $\beta$-sitosterol in streptozotocin-induced experimental hyperglycemia. Journal of diabetes, 3(1), 29-37.
[30]. Song, Y. S., Jin, C., \& Park, E. H. (2000). Identification of metabolites of phytosterols in rat feces using GC/MS. Archives of pharmacal research, 23(6), 599-604.

[31]. Moreno, J. J., \& Mitjavila, M. T. (2003). The degree of unsaturation of dietary fatty acids and the development of atherosclerosis. The Journal of nutritional biochemistry, 14(4), 182-195.

[32]. Vivancos, M., \& Moreno, J. J. (2005). $\beta$-Sitosterol modulates antioxidant enzyme response in RAW 264.7 macrophages. Free Radical Biology and Medicine, 39(1), 91-97.

[33]. Hsu, C. C., Kuo, H. C., \& Huang, K. E. (2017). The effects of phytosterols extracted from Diascorea alata on the antioxidant activity, plasma lipids, and hematological profiles in Taiwanese menopausal women. Nutrients, 9(12), 1320.

[34]. Suhaj, M. (2006). Spice antioxidants isolation and their antiradical activity: a review. Journal of food composition and analysis, 19(6-7), 531-537. 